\title{
Middle Pleistocene Ostracoda from a large freshwater lake in the presently dry Qaidam Basin (NW China)
}

\author{
STEFFEN MISCHKE ${ }^{1}$, ULRIKE HERZSCHUH ${ }^{2}$, ZHENCHENG SUN $^{3}$, ZIZHEN QIAO $^{4}$, NAIDA SUN $^{3} \&$ \\ ANJA M. ZANDER ${ }^{5}$ \\ ${ }^{1}$ Interdisciplinary Centre for Ecosystem Dynamics in Central Asia, Freie Universität Berlin, Malteserstr. 74-100, 12249 Berlin, Germany \\ (e-mail: smischke@web.de) \\ ${ }^{2}$ Alfred-Wegener-Institut Potsdam, Telegrafenberg, Potsdam, Germany \\ ${ }^{3}$ University of Petroleum, Department of Earth Science, Changping, Beijing 102200, PR China \\ ${ }^{4}$ Headquarter of Petroleum Exploration and Development of Qinghai Province, CNPC, Dunhuang 736202, PR China \\ ${ }^{5}$ Department of Geography, Philipps-Universität Marburg, Deutschhausstr. 10, 35037 Marburg/Lahn, Germany
}

\begin{abstract}
Ostracods of Middle Pleistocene age were recovered from an escarpment at the northeastern margin of the large Qarhan playa surface in the Qaidam Basin (NW China). The Middle Pleistocene age of the sampled Quan Ji section was determined by means of Optically Stimulated Luminescence (OSL) dating of seven sediment samples. Among the 31 ostracod taxa identified in total, only Eucypris gyirongensis, Leucocythere dorsotuberosa and Prionocypris gansenensis seem to be restricted to highaltitude sites in Central Asia whereas most taxa are known from a number of European and Siberian (Palaeoarctic) or even Holarctic sites. Laterally widespread sediments and the ostracods from the Quan Ji section suggest the formation of a large freshwater to oligohaline lake of at least several metres in depth in the Qaidam Basin, which is presently dry apart from a few shallow salt lakes. J. Micropalaeontol. 25(1): 57-64, April 2006.
\end{abstract}

KEYWORDS: Ostracoda, Qaidam Basin, NW China, palaeolake, Middle Pleistocene

\section{INTRODUCTION}

The Qaidam Basin at the northern margin of the Tibetan Plateau is a large intermontane basin, covering approximately $100000 \mathrm{~km}^{2}$ between $36^{\circ}$ and $39^{\circ} \mathrm{N}$ latitude and $90^{\circ}$ and $98^{\circ} \mathrm{E}$ longitude. Owing to the low annual precipitation $\left(38 \mathrm{~mm} \mathrm{a}^{-1}\right.$ in Golmud; Domrös \& Peng, 1988, Fig. 1), the basin represents a desert characterized by a typical Yardang topography of windshaped hills of lacustrine or playa sediments, and large playa lakes. Shallow salt lakes cover the lowermost depressions in the centre of the basin at 2675 m elevation above sea-level (asl) or in somewhat higher positions, whereas the peaks of the surrounding mountain ranges exceed $5000 \mathrm{~m}$ asl (W. Yang et al., 1995). Thick sequences of lacustrine sediments were investigated by means of numerous petroleum exploration drill holes and are exposed as low hilly remnants of rapid deflation. While these lake deposits were concurringly attributed to a former large inland lake by Chen \& Bowler (1986) and Hövermann \& Süßenberger (1986), the size and timing of the inland lake formation has been the subject of controversy (Chen \& Bowler, 1986; Hövermann \& Süßenberger, 1986; Hövermann et al., 1992). Ancient shoreline deposits about $120 \mathrm{~m}$ above the depression centre were attributed to Early or Middle Pleistocene age by Chen \& Bowler (1986), whereas similar deposits about $270 \mathrm{~m}$ above the lowermost part of the basin were regarded as Late Quaternary remnants of a large lake by Hövermann \& Süßenberger (1986), although an absolute age determination was not conducted. Ostracod shells served as a main proxy for palaeoenvironmental inferences and stratigraphical correlation but, in contrast to Pre-Quaternary Cenozoic ostracods (Exploration, 1988), Quaternary ostracod shells have been, if at all, poorly illustrated in publications so far. To overcome this insufficient state of shell documentation and to contribute to the discussion on the timing of the large inland lake formation, the authors studied the exposed Quan Ji section at the northeastern margin of the large Qarhan playa in the lowermost region of the basin (Fig. 1).

\section{MATERIAL AND METHODS}

An escarpment displaying thick sequences of fine-grained silty sediments with intercalations of aeolian and fluvial sands is exposed in the northeast of the Qarhan playa, one of the world's largest playa surfaces, covering $5856 \mathrm{~km}^{2}$ (Zheng et al., 1989). About $10 \mathrm{~km}$ to the north of the escarpment, a foothill range of the Qilian Mountains (Amunike Mountains) rises c.1000 m above the flat playa surface. Sediments of the escarpment are laterally continuous over the exposed distance of $c .2 \mathrm{~km}$ and dip c. $1.5^{\circ}$ towards the SSE, i.e. away from Amunike Mountains. Sediment samples from a sequence of $50 \mathrm{~m}$ thickness $\left(36^{\circ} 58^{\prime}\right.$ $27.6^{\prime \prime} \mathrm{N}, 96^{\circ} 15^{\prime} 33.3^{\prime \prime} \mathrm{E}, 2734 \mathrm{~m}$ asl) were collected and washed through $0.098 \mathrm{~mm}$ and $1 \mathrm{~mm}$ meshes for ostracod analysis. In addition, five samples of fine-grained, well-sorted sand regarded as wind-blown sand, as well as two samples of probably fluvial origin, were collected for Optically Stimulated Luminescence (OSL) dating. Optical dating is the only method with which the absolute ages of sediment burial can be determined. Natural occurring sedimentary minerals such as quartz and feldspar are generally used for dating. The applicable age range for optical dating is usually restricted by saturation of the quartz OSL signal and stability of the feldspar Infrared Stimulated Luminescence (IRSL) signal. Depending on the environmental dose rate and saturation behaviour of the quartz, a successful OSL application is limited to approximately $100 \mathrm{ka}$. The IRSL signal of feldspar usually saturates at higher doses and can hence be used to date much older deposits but is often affected by anomalous fading (see, for example, Wintle, 1973; Aitken, 1985), which leads to underestimation of the burial age. 


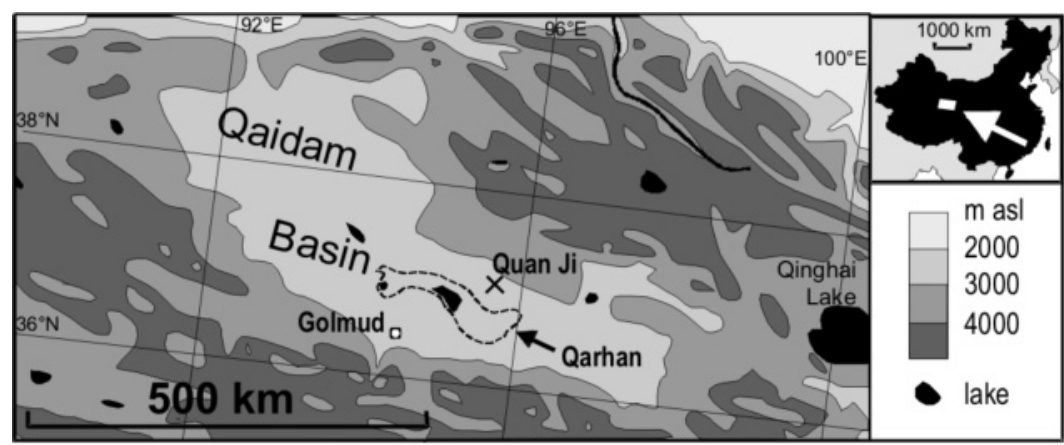

Fig. 1. Map showing the location of the sampled Quan Ji section in the northeast of the large Qarhan playa surface, indicated by the broken line.

For this study, equivalent dose determinations of sand-size potassium feldspar and quartz were carried out on a standard Risø TL/OSL reader (Bøtter-Jensen et al., 2002) using the single aliquot regeneration (SAR) protocol (Murray \& Wintle, 2000; Wallinga et al., 2000). A $200 \mathrm{~s}$ IR stimulation was applied to feldspars and IRSL detection used a blue transmitting filter pack (Schott BG39, Corning 7-59 and Schott GG 400) for the measurements. The dating approach on quartz using the SAR protocol with blue light stimulation and UV detection failed due to large scatter and saturation effects. Fading experiments were carried out on two feldspar samples over a period of three months. Forty-one days after irradiation, the samples lost 9-6\% of their initial IRSL signal and 3-0.5\% within the following 56 days.

Dose rates were determined by neutron activation analysis. Internal potassium contents of $9 \pm 1 \%$ and an alpha efficiency of $0.2 \pm 0.02$ was assumed (Mejdahl \& Christiansen, 1994). The sampled sequence mainly comprises lacustrine sediments (see below) but with regard to the escarpment morphology and the presentday conditions, a water content of $10 \pm 5 \%(15 \pm 5 \%$ for the lowermost sample) was adopted for age calculation.

\section{AGE ASSIGNMENT}

IRSL dating studies on seven samples from the $50 \mathrm{~m}$ thick sequence yielded ages between $110 \pm 17 \mathrm{ka}$ and $144 \pm 13 \mathrm{ka}$ for the upper $40 \mathrm{~m}$ of sediments and $176 \pm 17 \mathrm{ka}$ for the lowermost fluvial sand. The results obtained for the upper six samples are not in stratigraphic order and all cover the same age range within standard deviation. Associated equivalent doses range from $318 \pm 44$ Gy to $437 \pm 21$ Gy and dose rates show a wide variation in the section. They vary from $2.3 \pm 0.2 \mathrm{~Gy} \mathrm{ka}^{-1}$ to $3.1 \pm 0.2 \mathrm{~Gy} \mathrm{ka}^{-1}$. The highest equivalent dose was obtained for the lowermost sample from the fluvial sand.

Obtained IRSL ages for the feldspar fraction seem to imply a Late Pleistocene burial age sometime between Marine Isotope Stage (MIS) $5 \mathrm{c}$ and $5 \mathrm{e}$ for the upper $40 \mathrm{~m}$ of sediments but, with regard to the fading rate of $0.5-3 \%$, these ages represent minimum ages and probably underestimate the true deposition time interval significantly. Thus, a Middle Pleistocene age is very likely for the formation of the sampled sediment sequence and can be further specified to a late Middle Pleistocene age (MIS 7 or 6) taking the presence of Candona candida shells into account, which are considered to have appeared in the Qaidam Basin not earlier than c. $210 \mathrm{ka}$ bp (Yang et al., 1997).

\section{OSTRACOD ASSEMBLAGES}

In total, 31 ostracod taxa were recorded from the Quan Ji section (Pls 1-3). According to literature on Quaternary Ostracoda from the Qaidam Basin (Huang, 1964; Chen et al., 1990; Wang \& Shen, 1993; Sun et al., 1995; F. Yang et al., 1995, 1997; Liu et al., 1998) and from the neighbouring Qinghai Lake basin (Yang, 1988, Yang et al., 2002; Zhang et al., 1994), half of these taxa were recorded previously from deposits in the region (Table 1).

Eucypris gyirongensis, Leucocythere dorsotuberosa and Prionocypris gansenensis are the only three species from Quan Ji which do not have a Palaeoarctic distribution and which are probably restricted to high-altitude sites of Central Asia. Most other taxa are known from numerous sites of northern Asia and Europe, although some species, such as the cold stenothermal or oligothermophilic Candona weltneri, were not recorded from a position as far in the south as the Qaidam Basin until now (Meisch, 2000; and refs therein).

The shells of Paralimnocythere psammophila from Quan Ji represent the oldest specimens recorded so far. Until now, Recent and sub-Recent specimens of $P$. psammophila were recorded from Germany, France, Spain, the Ukraine (see refs in Meisch, 2000) and Scotland (Smith \& Horne, 2004). According to the record of sub-Recent specimens from the Qilian Mountains (China; Mischke et al., 2003) and the current study, $P$. psammophila occurs at least at the northern margin of the Tibetan Plateau since the Middle Pleistocene.

Three taxa of Ilyocypris could be identified due to the existence and number of tubercles and the appearance of so-called inner marginal ripplets of the left valve which are believed to be species-specific characters (Van Harten, 1979; Janz, 1994; Pl. 2). Existing or missing tubercles cannot be used for shell identification alone. Meisch (2000) reported on forms with and without tubercles for Ilyocypris decipiens and I. gibba, and Yang et al. (2002) have shown that there are all transitional stages between noded and unnoded shells of Ilyocypris gibba and I. echinata. Marginal ripplets in the posteroventral area of the inner lamella of the left valve were used by Van Harten (1979) for the first time as a shell characteristic to enable the distinction between different taxa of Ilyocypris.

The specimens here with tubercles from Quan Ji were identified as Ilyocypris bradyi and I. decipiens which may be distinguished by the different pattern of the marginal ripplets (Pl. 2). In I. bradyi, few marginal ripplets with an adjoining inner 


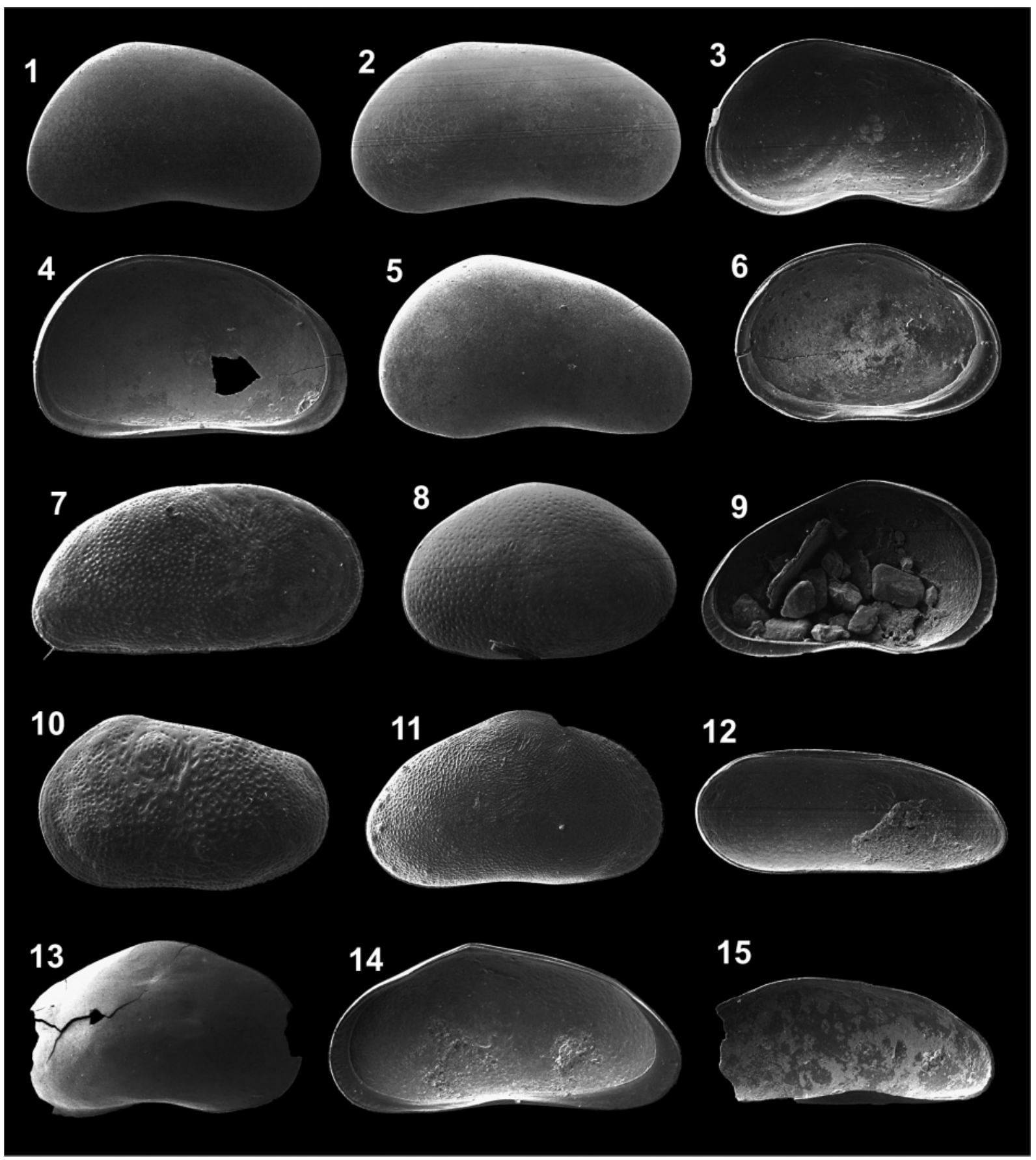

Explanation of Plate 1.

fig. 1. Candona candida,RV ext., length $1060 \mu \mathrm{m}$ (SMII8). figs 2, 3. Candona neglecta: 2, or RV ext., length $1100 \mu \mathrm{m}$ (SMII22); 3, ơ LV int., length $1110 \mu \mathrm{m}$ (SMIII31). figs 4, 5. Candona weltneri: 4, . LV int., length $1120 \mu \mathrm{m}$ (SMII10); 5, ơ RV ext., length $1120 \mu \mathrm{m}$ (SMI26). fig. 6. Cyclocypris ovum, LV int., length $530 \mu \mathrm{m}$ (SMI6). fig. 7. Cyprideis torosa, ơ RV ext., length $954 \mu \mathrm{m}$ (SMII2). fig. 8. Cypridopsis vidua, LV ext., length $740 \mu \mathrm{m}$ (SMIII27). fig. 9. Cypris pubera, juvenile, LV int., length $1740 \mu \mathrm{m}$ (SMIII30). fig. 10. Cytherissa lacustris, juvenile, LV ext., length $758 \mu \mathrm{m}$ (SMIII29). fig. 11. Eucypris dulcifons, juvenile, RV ext., length $813 \mu \mathrm{m}$ (SMI3). fig. 12. Darwinula stevensoni, LV int., length $710 \mu \mathrm{m}$ (SMIII25). fig. 13. Eucypris mareotica, RV ext., length $847 \mu \mathrm{m}$ (SMI4). fig. 14. Eucypris gyirongensis, juvenile, RV int., length $742 \mu \mathrm{m}$ (SMI30). fig. 15. Dolerocypris sp., RV int., length $465 \mu \mathrm{m}$ (SMI29). Specimens housed in the Interdisciplinary Centre for Ecosystem Dynamics in Central Asia of the Freie Universitaet Berlin, Germany.

list above are typically located relatively near the outer valve margin, whereas a band of numerous inconspicuous small ripplets may be found on left valves of $I$. decipiens (Van Harten,
1979; Janz, 1994). The smooth-shelled specimens from the current study of the recently described Ilyocypris sebeiensis show a number of distinct marginal ripplets without an adjoining 


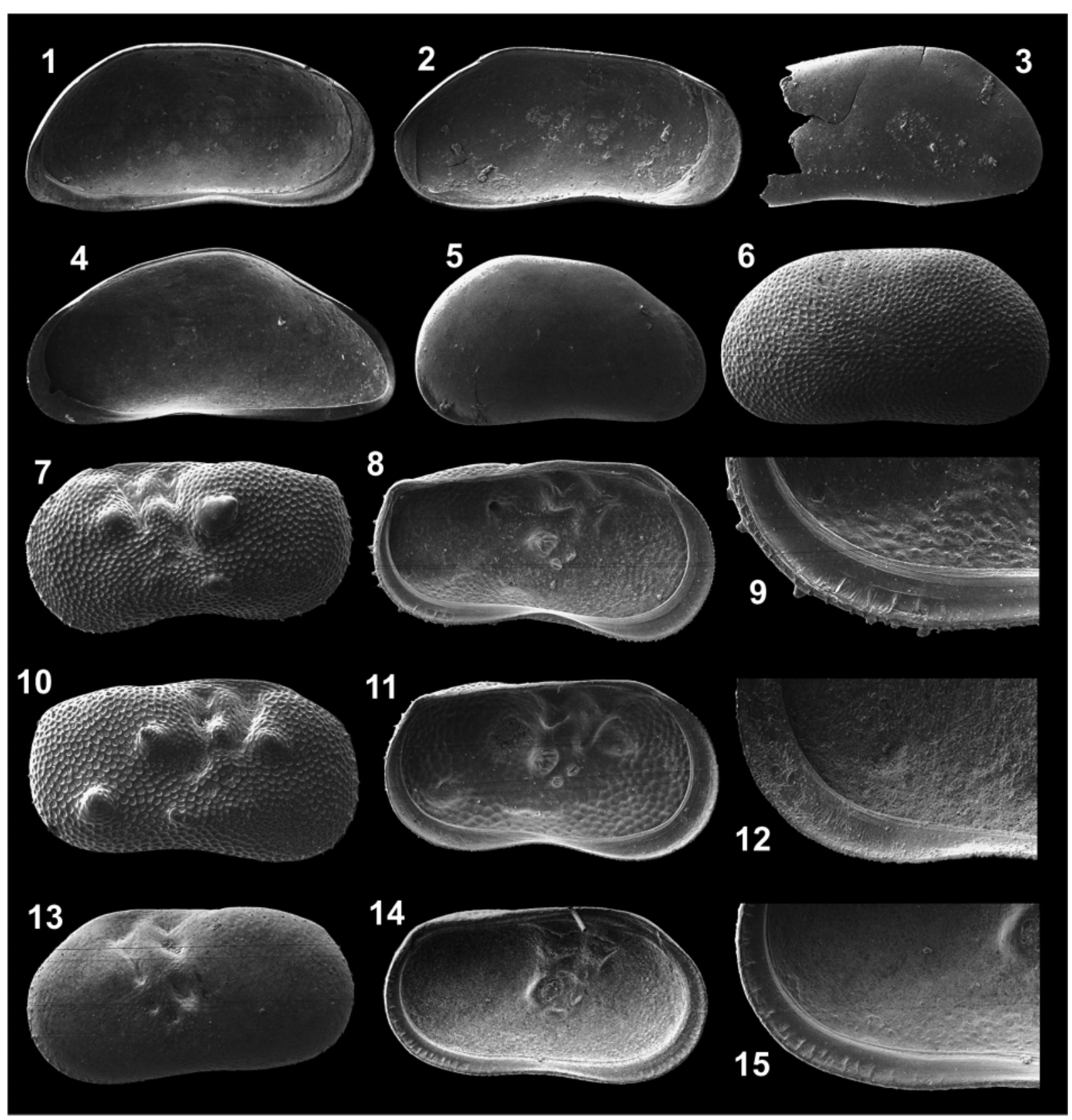

Explanation of Plate 2.

fig. 1. Fabaeformiscandona caudata, LV int., length $1140 \mu \mathrm{m}$ (SMIII26). fig. 2. Fabaeformiscandona fabaeformis, LV int., length $1040 \mu \mathrm{m}$ (SMI28). fig. 3. Fabaeformiscandona sp., LV ext., length $1240 \mu \mathrm{m}$ (SMI19). fig. 4. Fabaeformiscandona hyalina, RV int., length $1140 \mu \mathrm{m}$ (SMI2). fig. 5. Pseudocandona compressa, RV ext., length $942 \mu \mathrm{m}$ (SMII3). fig. 6. Pseudocandona compressa(?), juvenile, pitted surface, LV ext., length $620 \mu \mathrm{m}$ (SMIII32). figs 7-9. Ilyocypris bradyi, LV: 7, ext., length $1030 \mu \mathrm{m}$ (SMIII13); 8, int., length $1040 \mu \mathrm{m}$ (SMIII17); 9, marginal ripplets, enlargement of posteroventral area of specimen of fig. 8, width of cutting $346 \mu \mathrm{m}$. figs 10-12. Ilyocypris decipiens: 10, RV ext., length $835 \mu \mathrm{m}$ (SMII15); 11, LV int., length $811 \mu \mathrm{m}$ (SMII14); 12, LV int., marginal ripplets in posteroventral area, width of cutting $352 \mu \mathrm{m}$ (SMIII4). figs 13-15. Ilyocypris sebeiensis, LV: 13, ext., length $860 \mu \mathrm{m}$ (SMIII23); 14, int., length $787 \mu \mathrm{m}$ (SMIII22); 15, marginal ripplets, enlargement of posteroventral area of specimen of fig. 14, width of cutting $396 \mu \mathrm{m}$. Specimens housed in the Interdisciplinary Centre for Ecosystem Dynamics in Central Asia of the Freie Universitaet Berlin, Germany.

inner list (Yang et al., 2004; Pl. 2). The specific pattern of marginal ripplets may be used to distinguish shells of Ilyocypris sebeiensis from those of the similarly smooth-shelled taxa $I$. getica and I. inermis which have either inconspicuous marginal ripplets (I. getica) or which lack marginal ripplets at all (I. inermis; Janz, 1994; Meisch, 2000).
The shells of Limnocytherina cf. sanctipatricii from the Qaidam Basin differ in shape from shells of European sites by a slightly more expanded posterior part of female and male shells. Thus, dorsal and ventral margins of female shells are not approximately parallel as is typical for $L$. sanctipatricii but the ventral margin is diverging posteriorly from the dorsal margin 


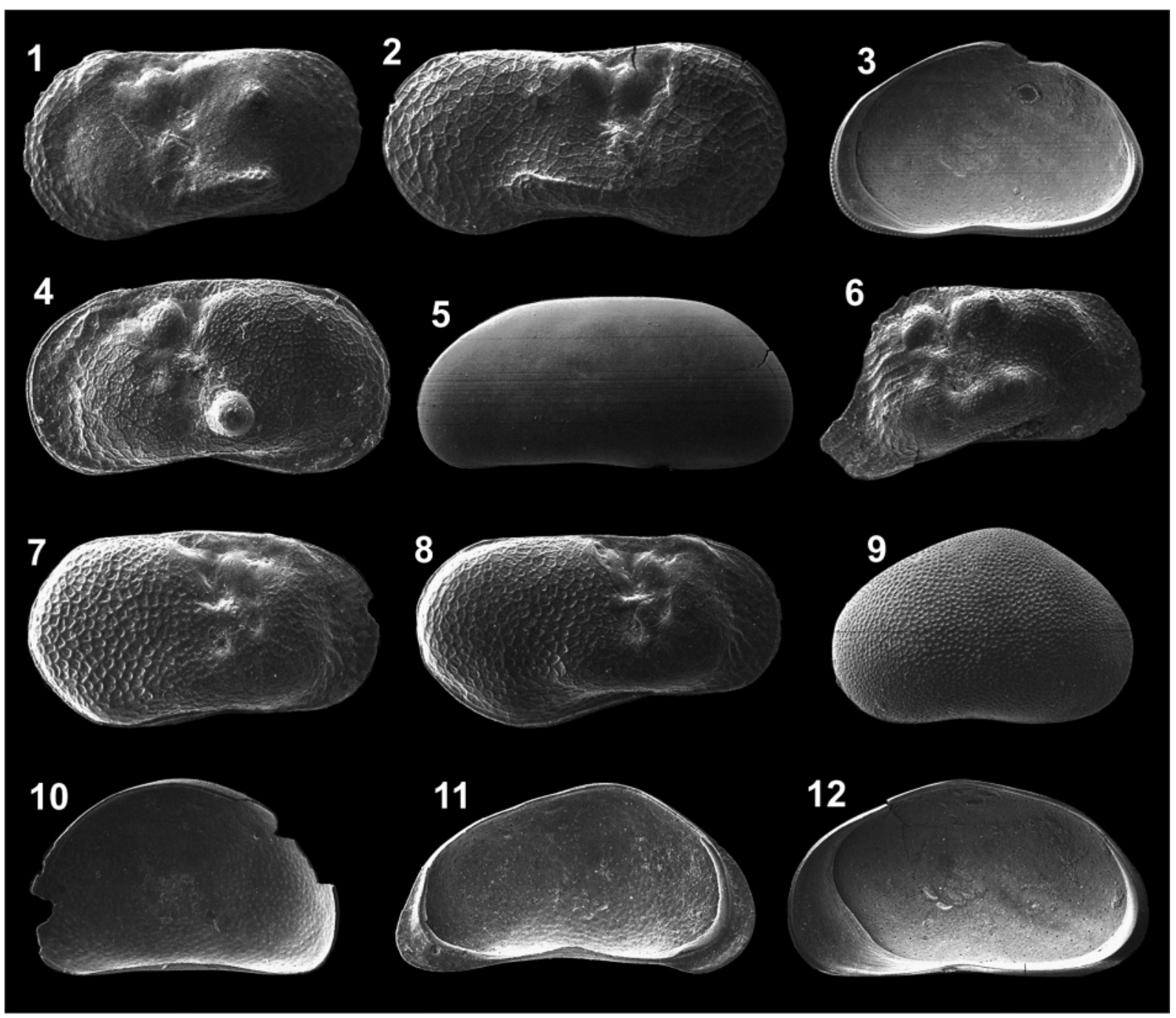

Explanation of Plate 3.

figs 1, 2. Leucocythere dorsotuberosa: 1, $9 \mathrm{LV}$ ext., length $788 \mu \mathrm{m}$ (SMI32); 2, ơ RV ext., length $752 \mu \mathrm{m}$ (SMI33). fig. 3. Heterocypris salina, RV int., length $1190 \mu \mathrm{m}$ (SMII24). fig. 4. Limnocythere inopinata, \&LV ext., length $600 \mu \mathrm{m}$ (SMI16). fig. 5. Herpetocypris chevreuxi, LV ext., length $2200 \mu \mathrm{m}$ (SMII21). fig. 6. Paralimnocythere psammophila, LV ext., length $563 \mu \mathrm{m}$ (SMII1). figs 7, 8. Limnocytherina cf. sanctipatricii: 7, \$RV ext., length $713 \mu \mathrm{m}$ (SMI22); 8, ơ RV ext., length $733 \mu \mathrm{m}$ (SMI23). fig. 9. Sarscypridopsis aculeata, RV ext., length $683 \mu \mathrm{m}$ (SMIII24). fig. 10. Potamocypris cf. arcuata, RV int., length $637 \mu \mathrm{m}$ (SMI11). fig. 11. Potamocypris smaragdina, LV int., length $674 \mu \mathrm{m}$ (SMI7). fig. 12. Prionocypris gansenensis, RV int., length $1300 \mu \mathrm{m}$ (SMI21). Specimens housed in the Interdisciplinary Centre for Ecosystem Dynamics in Central Asia of the Freie Universitaet Berlin, Germany.

(pers. comm. D. J. Horne). Living specimens from the Qaidam Basin should be collected for a firm identification of $L$. cf. sanctipatricii shells.

Identification to species level was not possible for Fabaeformiscandona sp. due to the sole occurrence or preservation of early juvenile stages and few fragments of adult shells (Pl. 2), and for a single large fragment of Dolerocypris sp. (P1. 1).

In addition to microfossils, a catfish-like skeleton (Siluridae; T. Klose, pers. comm.) was found embedded in a cross-stratified sand layer in the middle of the section.

\section{INFERENCES AND DISCUSSION}

The taxa recovered from the Quan Ji section are regarded as indicating fresh to oligohaline conditions. Of all 27 taxa with known salinity ranges, 15 are considered to thrive in fresh or oligohaline (salinity $<5 \%$ ) water bodies (Table 1 ). A further six taxa have been recorded from mesohaline conditions (5-18\%0) also. Two species may inhabit euhaline conditions (30-40\%), while three species even tolerate hypersaline $(>40 \%$ ) waters. However, all taxa are known from oligohaline water bodies as well (Table 1).

Cytherissa lacustris, Limnocytherina cf. sanctipatricii, Fabaeformiscandona caudata and, to a lesser degree, Candona neglecta (e.g. Danielopol et al., 1993) are regarded as characteristic of the profundal zone of a deep lake, whereas most other taxa hint towards shallower lake conditions (data compilation in Meisch, 2000). In addition, the high number of taxa points towards a relatively shallow lake of several metres depth only, rather than a permanently deep lake. However, the recorded ostracods, the fine silty sediments and the laterally continuous bedding of 
S. Mischke et al.

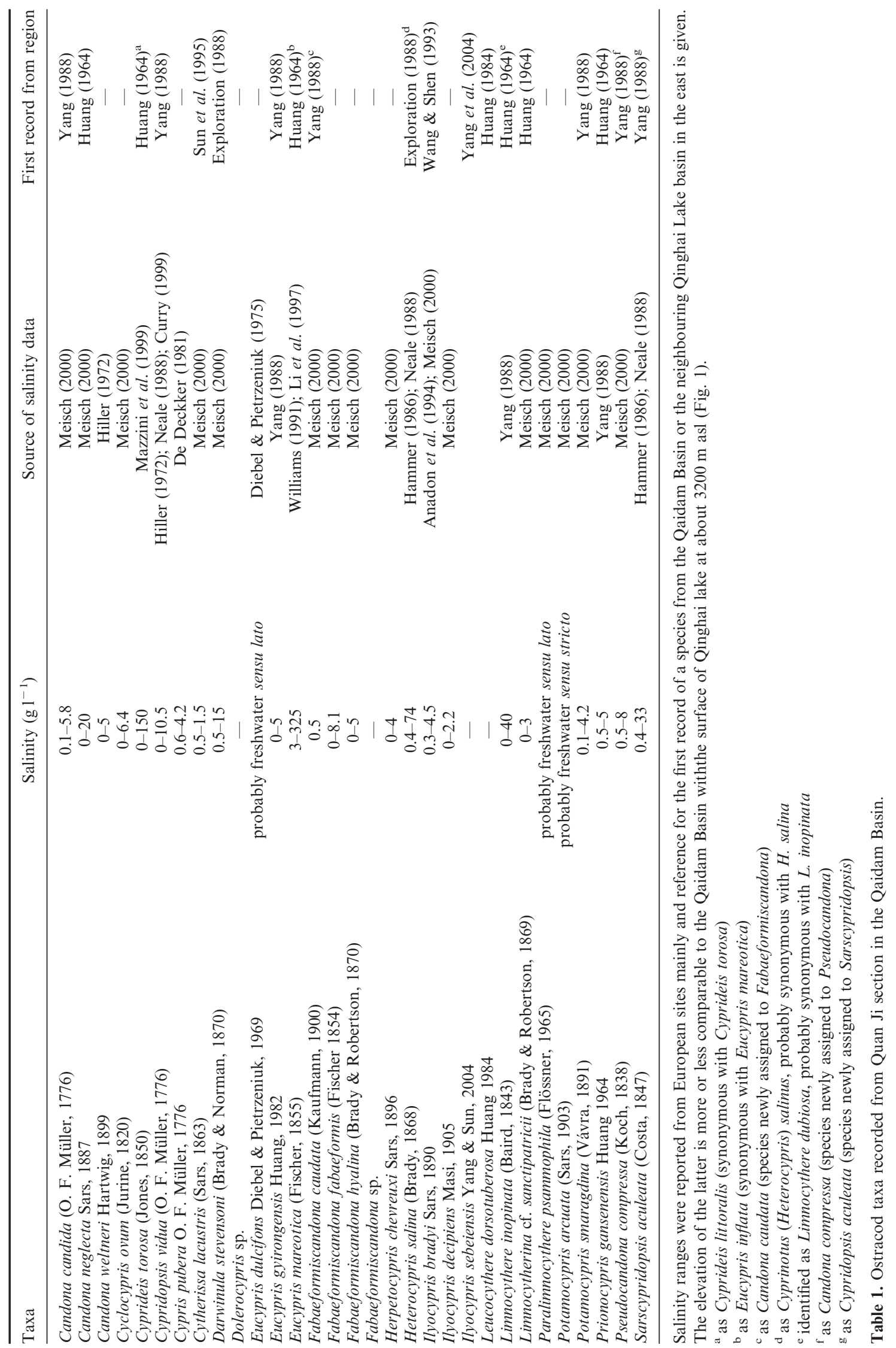


almost horizontal sediment units over a distance of at least $2 \mathrm{~km}$ are evidence for a former large freshwater or oligohaline lake in the eastern Qaidam Basin, possibly characterized by more saline lagoons and/or temporary stages of increased salinity levels. The catfish-like skeleton (Siluridae) from Quan Ji section further points to the former existence of a perennial water body of low salinity. In contrast to the depositional environment during the large lake period, contemporary sediment accumulation in the study area is controlled by halite formation in shallow hypersaline playa lakes at sites lower than the sampled escarpment (Schubel \& Lowenstein, 1997) or by locally restricted sporadic heavy precipitation events triggering flash floods and sand and gravel transport from the near Amunike Mountain range as well as by aeolian sand deposition at sites above (observation by the authors).

The inference of a Middle Pleistocene large lake in the Qaidam Basin arose from an initial study based on detailed taxonomical analysis of micro-organisms from a thick sequence of predominantly lake sediments. A large inland lake in the Qaidam Basin was inferred earlier from remnants of shoreline deposits and its relation to the present-day topography. Chen \& Bowler (1986) postulated a large inland lake, covering c. $59000 \mathrm{~km}^{2}$ or half the size of the Qaidam Basin, based on shoreline relicts at about $2800 \mathrm{~m}$ asl (i.e. $125 \mathrm{~m}$ above the present-day Qarhan playa). Although no dating results were available, Chen \& Bowler (1986) suggested an Early to Middle Pleistocene formation of a large lake considering the age of underlying strata.

Higher elevated shoreline deposits, at about $2950 \mathrm{~m}$ asl, were described by Hövermann \& Süßenberger (1986) and Hövermann et al. (1992). A $300 \mathrm{~m}$ deep freshwater lake of huge size $\left(70000 \mathrm{~km}^{2}\right)$ was suggested and attributed to ${ }^{14} \mathrm{C}$-dated clastic sediments in wells in the central part of the basin (Hövermann \& Süßenberger, 1986; Hövermann et al., 1992). Radiocarbon ages of these sediments ranged between 32 and $24{ }^{14} \mathrm{C} \mathrm{ka} \mathrm{bp}$, in contradiction to those of halite deposits from similar wells, suggesting that hot and dry conditions prevailed since $32{ }^{14} \mathrm{C}$ ka bp (Huang \& Chen, 1990) or even earlier between 50 and $30{ }^{14} \mathrm{C}$ ka bp (Zhang et al., 1995). Halite deposits can be found below c. $2700 \mathrm{~m}$ asl, pointing towards very shallow conditions during the salt-forming stage of the lake (Chen \& Bowler, 1986). Contrary to the findings of Hövermann \& Süßenberger (1986) and Hövermann et al. (1992), remnants of shoreline deposits at $2704 \mathrm{~m}$ asl (i.e. about $250 \mathrm{~m}$ lower than those reported by Hövermann et al. (1992)) yielded radiocarbon ages between 39 and $29{ }^{14} \mathrm{C} \mathrm{ka}$ bp and were regarded as indicating a much smaller and shallower but still large freshwater or slightly saline lake in the late MIS 3 (Chen \& Bowler, 1986).

The large lake inferred from the ostracods of the Middle Pleistocene Quan Ji section may correspond with the Early to Middle Pleistocene large inland lake suggested by Chen \& Bowler (1986). However, scanty existing data do not provide a sound basis either for a correlation of the Quan Ji sediments with shoreline deposits, or for depth and area inferences of the large Middle Pleistocene lake. In general, former lake extent inferences based on the present-day topography must be regarded as very speculative until there is more detailed knowledge on the spatial and temporal pattern of sediment accumulation in the Qaidam Basin. The tectonic activity of this region at the northern margin of the Tibetan Plateau (e.g. Van der Woerd et al., 2000), as well as the strong deflation of the easily erodible basin infill, complicate inferences of the former lake extent.

\section{CONCLUSIONS}

A sediment sequence of $50 \mathrm{~m}$ thickness in the eastern Qaidam Basin yielded very well-preserved ostracod shells of Middle Pleistocene age. According to the lateral extent of fine-grained lake sediments and the Recent ecological requirements of the 31 ostracod taxa recovered from the section, a large freshwater lake of at least several metres depth existed in the Middle Pleistocene in the Qaidam Basin. Inferred primarily fresh to oligohaline conditions of the lake are in marked contrast to the pronounced aridity in the region today. Further studies are needed to evaluate the evolution and size of the former lake.

\section{ACKNOWLEDGEMENTS}

Funding was provided by the Deutsche Forschungsgemeinschaft (DFG) and the Deutscher Akademischer Austauschdienst (DAAD). The authors wish to thank David J. Horne and an anonymous reviewer for their thorough reviews and John Gregory for many helpful comments.

\section{Manuscript received 4 February 2005 Manuscript accepted 21 September 2005}

\section{REFERENCES}

Aitken, M. 1985. Thermoluminescence dating. Academic Press, London, 395pp.

Anadon, P., Utrilla, R. \& Julià, R. 1994. Palaeoenvironmental reconstruction of a Pleistocene lacustrine sequence from faunal assemblages and ostracode shell geochemistry, Baza Basin, SE Spain. Palaeogeography, Palaeoclimatology, Palaeoecology, 111: 191-205.

Bøtter-Jensen, L., Bulur, E., Murray, A.S. \& Poolton, N.R.J. 2002. Enhancements in luminescence measurement techniques. Radiation Protection Dosimetry, 101: 119-124.

Chen, K. \& Bowler, J.M. 1986. Late pleistocene evolution of salt lakes in the Qaidam Basin, Qinghai Province, China. Palaeogeography, Palaeoclimatology, Palaeoecology, 54: 87-104.

Chen, K., Bowler, J.M. \& Kelts, K. 1990. Palaeoclimatic evolution within the Qinghai-Xizang (Tibet) Plateau in the last 40000 years. Quaternary Sciences, 3: 21-31 [in Chinese with English abstract].

Curry, B.B. 1999. An environmental tolerance index for ostracodes as indicators of physical and chemical factors in aquatic habitats. Palaeogeography, Palaeoclimatology, Palaeoecology, 148: 51-63.

Danielopol, D.L., Handl, M. \& Yin, Y. 1993. Benthic ostracods in the pre-alpine deep lake Mondsee: Notes on the origin and distribution. In: McKenzie, K.G. \& Jones, P.J. (Eds), Ostracoda in the Earth and Life Sciences. Proceedings of the $11^{\text {th }}$ International Symposium on Ostracoda, Warrnambool, Victoria, Australia. A.A. Balkema, Rotterdam, 465-480.

De Deckker, P. 1981. Ostracods of athalassic saline lakes. A review. Hydrobiologia, 81: 131-144.

Diebel, K. \& Pietrzeniuk, E. 1975. Mittel- und jungpleistozäne Ostracodenfaunen des Raums Potsdam - Brandenburg - Rathenow in stratigraphischer und ökologischer Sicht. Zeitschrift für geologische Wissenschaften, 3: 1197-1233.

Domrös, M. \& Peng, G. 1988. The climate of China. Springer, Berlin, 361pp.

Exploration and Development Research Institute, Qinghai Petroleum Administration \& Nanjing Institute of Geology and Palaeontology, Academia Sinica 1988. Tertiary ostracode fauna from Qaidam Basin, NW China. Nanjing University Press, 190pp. 
Hammer, U.T. 1986. Saline lake Ecosystems of the World. Monographiae Biologicae, 59. Kluwer Academic Publishers, Dordrecht, $614 \mathrm{pp}$.

Hiller, D. 1972. Untersuchungen zur Biologie und zur Ökologie limnischer Ostracoden aus der Umgebung von Hamburg. Archiv für Hydrobiologie Supplement-Band, 40: 400-497.

Huang, B. 1964. Ostracods from Gansen district, Chaidam Basin. Acta Palaeontologica Sinica, 12: 241-270.

Huang, B. 1984. Pliocene and early Pleistocene Ostracoda from Gonghe Basin, Qinghai. Memoirs of Nanjing Institute of Geology and Palaeontology, Academia Sinica, 19: 1-22.

Huang, Q. \& Chen, K. 1990. Palaeoclimatic fluctuation fashion of Qarhan Salt Lake in Qaidam Basin in the past 730000 years. Quaternary Science, 9: 205-212 [in Chinese with English abstract].

Hövermann, J. \& Süßenberger, H. 1986. Zur Klimageschichte Hoch- und Ostasiens. Berliner Geographische Studien, 20: 173-186.

Hövermann, J., Lehmkuhl, F. \& Süßenberger, H. 1992. Neue Befunde zur Paläoklimatologie Nordafrikas und Zentralasiens. Abhandlungen der Braunschweigischen Wissenschaftlichen Gesellschaft, 43: 127-150.

Janz, H. 1994. Zur Bedeutung des Schalenmerkmals 'Marginalrippen' der Gattung Ilyocypris (Ostracoda, Crustacea). Stuttgarter Beiträge zur Naturkunde Serie B, 206: 1-19.

Li, Y., Li, B., Wang, G., Li, S. \& Zhu, Z. 1997. Ostracoda and its environmental significance at the ancient Tianshuihai Lake of the West Kunlun. Journal of Lake Science, 9: 223-230.

Liu, Z., Wang, Y., Chen, Y., Li, X. \& Li, Q. 1998. Magnetostratigraphy and sedimentologically derived geochronology of the Quaternary lacustrine deposits of a $3000 \mathrm{~m}$ thick sequence in the central Qaidam basin, western China. Palaeogeography, Palaeoclimatology, Palaeoecology, 140: 459-473.

Mazzini, I., Anadon, P., Barbieri, M.et al. 1999. Late Quaternary sea-level changes along the Tyrrhenian coast near Orbetello (Tuscany, central Italy): palaeoenvironmental reconstruction using ostracods. Marine Micropaleontology, 37: 289-311.

Meisch, C. 2000. Freshwater Ostracoda of Western and Central Europe. Spektrum, Heidelberg, 522pp.

Mejdahl, V. \& Christiansen, H.H. 1994. Procedures used for luminescence dating of sediments. Quaternary Science Reviews, 13 403-406.

Mischke, S., Herzschuh, U., Kürschner, H., Fuchs, D., Zhang, J., Meng, F. \& Sun, Z. 2003. Sub-Recent Ostracoda from Qilian Mountains (NW China) and their ecological significance. Limnologica, 33 280-292.

Murray, A.S. \& Wintle, A.G. 2000. Luminescence dating of quartz using an improved single-aliquot regenerative-dose protocol. Radiation Measurements, 32: 57-73.

Neale, J.W. 1988. Ostracods and palaeosalinity reconstructions. In: De Deckker, P., Colin, J.P. \& Peypouquet, J.P. (Eds), Ostracoda in the earth sciences. Elsevier, Amsterdam, 125-155.

Schubel, K.A. \& Lowenstein, T. 1997. Criteria for the recognition of shallow-perennial-saline-lake halites based on recent sediments from the Qaidam Basin, western China. Journal of Sedimentary Research, 67: 74-87.

Smith, R.J. \& Horne, D.J. 2004. The first British record of Paralimnocythere psammophila (Flössner, 1965) (Ostracoda, Cytheroidea, Limnocytheridae). Journal of Micropalaeontology, 23: 133-134.

Sun, Z., Li, J., Zhan, S., Wang, P., Wang, T. \& Li, Y. 1995. Areal distribution of Quaternary ostracod assemblages and ist main control- ling factor in Chaidamu Basin, NW China. In: Riha, J. (Ed.), Ostracoda and Biostratigraphy. Balkema, Rotterdam, 277-281.

Van Harten, D. 1979. Some new shell characters to diagnose the species of the Ilyocypris gibba-biplicata-bradyi group and their ecological significance. In: Serbian Geological Society (Ed.), Taxonomy, biostratigraphy and distribution of ostracodes. Proceedings of the $7^{\text {th }}$ International Symposium on Ostracodes. Serbian Geological Society, Belgrade, 71-76.

Van der Woerd, J., Ryerson, F.J., Tapponnier, P.et al. 2000. Uniform slip-rates along the Kunlun Faults: Implications for seismic behaviour and large-scale tectonics. Geophysical Research Letters, 27: 2353-2356.

Wallinga, J., Murray, A.S. \& Wintle, A. 2000. The single-aliquot regenerative-dose (SAR) protocol applied to coarse-grain feldspar. Radiation Measurements, 32: 529-533.

Wang, Q. \& Shen, Z. 1993. Ostracoda research. In: Shen, Z., Cheng, G., Le, C. \& Liu, S. (Eds), The division and sedimentary environment of Quaternary salt-bearing strata in Qaidam Basin. Geological Publishing House, Beijing, 62-67 [in Chinese with English abstract].

Williams, W.D. 1991. Chinese and Mongolian saline lakes: a limnological overview. Hydrobiologia, 210: 39-66.

Wintle, A.G. 1973. Anomalous fading of thermoluminescence in mineral samples. Nature, 245: 143-144.

Yang, F. 1988. Distribution of the brackish-salt water ostracods in northwestern Qinghai Plateau and its geological significance. In: Hanai, T., Ikeya, N. \& Ishizaki, K. (Eds), Evolutionary Biology of Ostracoda, its fundamentals and applications. Elsevier, Amsterdam, 519-530.

Yang, F., Sun, Z. \& Cao, C. 1995. Discovery of a spinose new genus Qaidamocypris from terrestrial Quaternary in the Qaidam Basin and its significance. Acta Micropalaeontologica Sinica, 12: 275-283.

Yang, W., Spencer, R.J., Krouse, H.R., Lowenstein, T.K. \& Casas, E. 1995. Stable isotopes of lake and fluid inclusion brines, Dabusun Lake, Qaidam Basin, western China: Hydrology and paleoclimatology in arid environments. Palaeogeography, Palaeoclimatology, Palaeoecology, 117: 279-290.

Yang, F., Sun, Z., Ma, Z. \& Zhang, Y. 1997. Quaternary ostracode zones and magnetotratigraphic profiles in the Qaidam Basin. Acta Micropalaeontologica Sinica, 14: 378-390.

Yang, F., Sun, Z., Zhang, Y. \& Qiao, Z. 2002. Taxonomic significance of nodal ornamentation of Quaternary genus Ilyocypris (Ostracoda) from Qaidam Basin, Qinghai Province. Acta Micropalaeontologica Sinica, 19: 15-32.

Yang, F., Sun, Z., Qiao, Z. \& Zhang, Y. 2004. Revision of the diagnosis of the genus Qinghaicypris Huang, 1979 (Ostracoda) and the environmental significance of its type species. Acta Micropalaeontologica Sinica, 21: $367-381$.

Zhang, P., Zhang, B., Qian, G., Li, H. \& Xu, L. 1994. The study of paleoclimatic parameter of Qinghai Lake since Holocene. Quaternary Sciences, 8: 225-238.

Zhang, B., Zhang, P., Lowenstein, T.K. \& Spencer, R.J. 1995. Time range of the great ice age of the last glacial stage and its related geological event of playa in the Qinghai-Xizang (Tibet) Plateau. Quaternary Sciences, 3: 193-201 [in Chinese with English abstract].

Zheng, M., Xiang, J., Wei, X. \& Zheng, Y. 1989. Saline lakes on the Qinghai-Xizang (Tibet) Plateau. Beijing Scientific and Technical Publishing House, Beijing, 431pp. [in Chinese]. 